\title{
John Keats and John Clare: The Ivory Tower Poets of British Romanticism
}

Moslem Ahmadi *

Faculty of Persian and Foreign Languaes, Tabriz University Po box 29 Bahman Boulevard, Tabriz 5166614766, Iran

Corresponding Author: Moslem Ahmadi, E-mail: moslemahmadiapril1992@gmail.com

\section{ARTICLE INFO}

Article history

Received: December 11, 2017

Accepted: January 15, 2018

Published: February 28, 2018

Volume: 9 Issue: 1

Advance access: January 2018

Conflicts of interest: None

Funding: None

\begin{abstract}
The focus of this research is in the area of the British Romantic literature. Such a study is important in order to demonstrate how the great poets of the British Romantic literature possess the potential to be regrouped under new labels based on the existence of similar attitudes in their literary works. The findings from this research provide evidence that the labels by means of which the scholars group different poets of an age are not fixed and they are susceptible to change. The main conclusion drawn from this study is that new literary labels can be an excellent methodology for determining the real attitudes which influence different poets' literary works. This paper recommends that new literary labels can be an excellent way for a better understanding of literary works.
\end{abstract}

Key words: British, Romantic, poets, regroup, labels.

To God and to my twin brother, Mosleh Ahmadi for all their kindness and generosity.

\section{INTRODUCTION}

In their poetry poetry, John Keats and John Clare seem to embody the same individuality which Alfred de Vigny adopted in his poetry. This particular individuality is evident in all of John Keats' poems from his first sonnet called "On First Looking into Chapman's Homer" (1816) to Lamia Part II (1820). John Keats opens his Endymion: A Poetic Romance (1818) with the famous line, "A thing of beauty is a joy forever" (Greenblatt \& Abrams, 2006). This superficial and earthly beauty becomes the main theme of his entire poetry at the expense of all practical issues. This is what makes Keats' poetic career resemble that of de Vigny's. John Clare's poetry is limited only to the description of rural settings. Accordingly, this limitation makes his poetic career resemble that of Alfred de Vigny's. Accordingly, the present study aims to find out whether these two poets of British Romanticism can be grouped under one common label or not. To facilitate the process of achieving this aim, the overall research aim is divided into two main goals. On the one hand, this study intends to find out whether the systems of thought behind these two poets' works is the same. On the other hand, this study intends to find out why these two poets can be grouped together under one common term despite their slight differences in their poetic attitudes.

\section{DISCUSSION}

Prior to addressing the main topic of this paper, it is necessary to define the specific label by means of which I attempt to group the aforementioned literary figures together: "ivory tower". The origin of the term "ivory tower" goes back to ancient and biblical texts: in the biblical Song of Songs, the lover tells his beloved, "Thy neck is as a tower of ivory; thine eyes like the fishpools in Heshbon" and Penelope, longing for her spouse's homecoming, says, "Those dreams that pass through the gate of sawn ivory deceive men, bringing words that find no fulfilment. But those that come forth through the gate of polished horn bring true issues to pass" (Shapin, 2012). Since the semantic features of language have been changing constantly, this term has undergone the same changes. From the twelfth century, the term "ivory tower" was utilized to describe the Virgin Mary, mother of Jesus (Shapin, 2012). In the nineteenth century, the meaning of the term changed along with its usage from religion to aesthetics (Shapin, 2012). This change occurred due to Charles Augustin Sainte-Beuve's poem called "Pensées d'août, à M. Villemain" (Shapin, 2012). This poem attacks the French poet Alfred de Vigny who became too isolated: de Vigny's marital life ended up in a disaster, his mistress betrayed him, and he severed his ties with his friends in the Romantic movement (Shapin, 2012). In 1838, de Vigny abandoned publishing and went on to write verse about his inner life during his retirement in his estate called Angoulême (Shapin, 2012). From that time onwards, the term is usually utilized derogatorily 
to demonstrate an attitude or a method of living severed from the quotidian world and indifferent or hostile to practical issues; more characteristically, it is employed to demonstrate an artistic theory and practice isolated from moral, political, and social concerns or effects (Abrams \& Harpham, 2009). It is this last definition of the term on which my comparison is based. A brief discussion of the background in which English Romanticism took shape is indispensable to a better understanding of Keats' and Clare's different attitudes towards poetry and society. English Romanticism coincided with the shifting of England from an agricultural society to an industrial nation, the American Independence, and the French Revolution (Greenblatt \& Abrams, 2006). The different attitudes towards French Revolution were treated in books such as Mary Wollstonecraft's $A$ Vindication of the Rights of Men (1790), Edmund Burke's Reflections on the Revolution in France (1790), Tom Paine's Rights of Man (1791-92), and William Godwin's Enquiry Concerning Political Justice (1793) (Greenblatt \& Abrams, 2006). The last work had a profound influence on Wordsworth and Shelley (Greenblatt \& Abrams, 2006). But the English supporters were disappointed as the French Revolution turned into the Reign of Terror (Greenblatt \& Abrams, 2006). Accordingly, all the English writers and poets of the early period of the English Romanticism had liberal tendencies. These liberal tendencies continued among the second group of Romantic poets such as Percy Bysshe Shelley, Lord Byron, and others despite the time distance between them and the French Revolution. For example, Shelley supported the Greek struggle for independence against the Turkish Empire in his lyrical drama called Hellas (1822) (Drabble, 2000). This road was also taken by Byron in his epic satire Don Juan (1819-24) which criticises social and sexual hypocrisy and sentimentality (Drabble, 2000).

However, John Keats' attitude appears unique in these times of extreme liberalism. Throughout his poetic career, he was preoccupied with a delightful sense of beauty. Unlike Shelley who regarded the world of sense experience as a shadow of the ideal and Platonic world (Greenblatt \& Abrams, 2006), John Keats was delighted at the sheer existence of objects separate from himself and identified himself with them (Greenblatt \& Abrams, 2006). The people, animals, things, and places in which Keats sought sensuous beauty were the main factors for the detachment of his poetry from the practical and everyday world. To put it another way, Keats' poetry reflects that aspect of the world which the people of the practical and everyday world had completely forgotten. A brief review of John Keats' most important works verifies the aforementioned statement. In 1816, John Keats discovered George Chapman's sixteenth-century translation of The Iliad which he glorified in On First Looking into Chapman's Homer for its release from the limitations of Alexander Pope's couplet version and for Homer's indirect influence on him (Sanders, 1994). In this sonnet, John Keats addresses a past literary translation and its influence on him instead of addressing the practical and everyday world as well as all its important events. John Keats' Endymion relates Endymion's retreat from the external life to the inner world of Endymion's soul and from Endymion's self to his deeper self (Volceanov, 2007). Since Endymion is John Keats' alter-ego in his quest for beauty in life (Volceanov, 2007), it can be seen as the point from which John Keats forsakes the practical and everyday world for sensuous beauty. Endymion becomes enamoured of Cynthia, the moon and descends to the underworld in quest for her (Drabble, 2000). In this work, Keats' persona leaves the practical and everyday world for the underworld in search of sensuous beauty. Accordingly, the place where Keats' persona searches for sensuous beauty detaches him from the real world. The mythic figure of sensuous beauty detaches Keats from the present world twice. Prior to finishing Hyperion, John Keats left the work unfinished when he considered Milton's influence as a threat to his individuality (Greenblatt \& Abrams, 2006). The theme of the nature of verse and the nature and the development of the poet underlies this allegoric poem (Drabble, 2000). In this poem like Endymion, Keats addresses his distinct individuality and the process of his poetic development by means of Greek mythology which detach him from the real world much more. John Keats' next work called Lamia (1820) puts a greater emphasis on his interest in sensuous beauty as it is evident in Lamia's superficial beauty and her true nature as a serpent. The treatment of Keats' narrative poem The Eve of St Agnes (1820) with a remote time period and sensual love

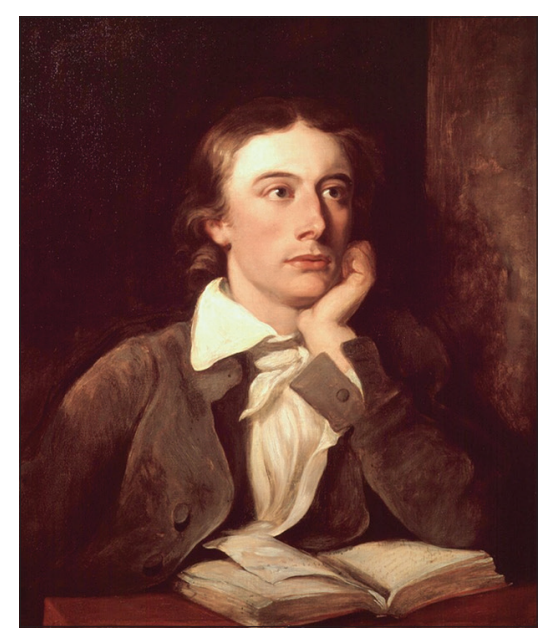

Figure 1. John Keats by William Hilton.

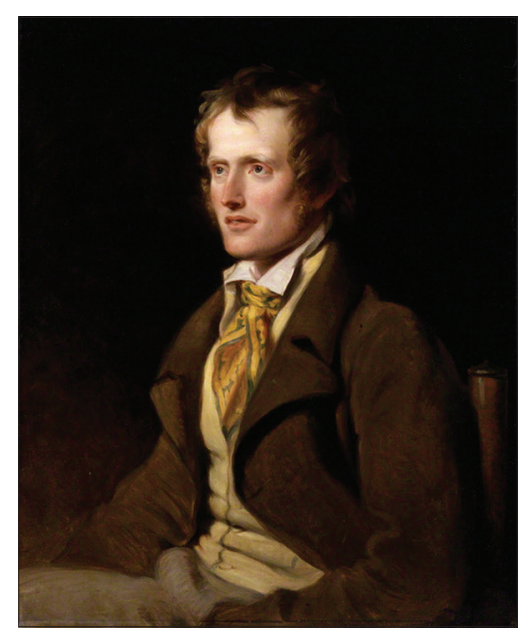

Figure 2. John Clare by William Hilton. 
makes this work a sharp contrast to the real world. In Ode on a Grecian Urn (1820), the superficial beauty of an inanimate object, i.e., an urn detaches Keats' mind from the outside world. In the aforementioned ode, Keats equates an impracti'cal aspect of life, i.e., superficial beauty with truth (Volceanov, 2007). In this ode, Keats deems the world depicted on the urn better than the outside world. In Ode to Psyche (1820), John Keats makes a gleeful sanctuary from the real world, i.e., an imaginary world to worship Psyche the goddess (Volceanov, 2007). The imaginary world of this poem demonstrates that John Keats' detachment from his contemporary world is full to the brim. In To Autumn (1820), John Keats' focus on an inanimate aspect of the nature, i.e., the autumn causes his detachment from the practical and everyday life. In this poem, he celebrates only those aspects of the real world which best describe the superficial beauty of the autumn. John Keats even introduced a term called "negative capability" in an 1817 letter to exposit a literary quality, i.e., "when man is capable of being in uncertainties, mysteries, doubts, without any irritable reaching after fact and reason" (Abrams \& Harpham, 2009). Here John Keats blatantly admits his indifference to anything practical. In the same letter, John Keats even goes so far and accuses Coleridge of verisimilitude in his verse (Abrams \& Harpham, 2009).

Like John Keats, John Clare's attitude towards poetry and life appears unique amongst his Romantic contemporaries. John Clare was an early $19^{\text {th }}$ century poet of nature (Greenblatt \& Abrams, 2006). This tendency was what detached him from the practical and everyday life. A quick review of his most important works demonstrates his detachment from the current trends of his period. In 1820, he published his Poems Descriptive of Rural Life and Scenery (Greenblatt \& Abrams, 2006). As the name of this poetic collection suggests, he was infatuated with the superficial beauty of rural life and scen-ery as opposed to more practical aspects and current trends of the world. John Clare continues the same tendency towards rural life in his other three poetic collections called The Village
Minstrel (1821), The Shepherd's Calendar (1827), and The Rural Muse (1835).

\section{CONCLUSION}

The analysis done in this paper demonstrates that John Keats and John Clare have adopted a similar system of thought in their poetry, i.e., detachment from the practical and everyday life. It also reveals a great difference between the two figures. This difference is due to the different causes contributing to their indifferent tendency towards the outside world: whereas John Keats' infatuation with sensuous beauty impelled him to ignore the everyday and practical world, John Clare's infatuation with rural life caused his detachment from the same world. Finally, it can be said since both figures share the same indifferent tendency towards their contemporary world, they can be grouped together as The Ivory Tower Poets of British Romanticism due to the influence of isolation from the practical reality on their literary careers.

\section{REFERENCES}

Abrams, M. H., \& Harpham, G. G. (2009). A Glossary of Literary Terms. (11 ${ }^{\text {th }}$ ed.). Boston: Wadsworth Cengage Learning.

Drabble, Margaret. (2000). The Oxford Companion to English Literature. (6 ${ }^{\text {th }}$ ed.). Oxford: Oxford University Press.

Greenblatt, Stephen, and Abrams, M. H. (2006). The Norton Anthology of English Literature. ( $8^{\text {th }}$ ed.). New York: W. W. Norton \& Company.

Sanders, Andrew. (1994). The Short Oxford History of English Literature. Oxford: Clarendon Press.

Shapin, Steven. (2012). The Ivory Tower: the history of a figure of speech and its cultural uses. BJHS 45(1): 1-27.

Volceanov, George. (2007). A Survey of English Literature from Beowulf to Jane Austen. (3 ${ }^{\text {rd }}$ ed.). Bucharest: Editura Fundatiei Romania de Maine. 